\title{
A MARKeT FOR Justice: A First EMPIRICAL LOOK AT THIRD PARTY LITIGATION FUNDING
}

\author{
David S. Abrams and Daniel L. Chen*
}

\begin{abstract}
The alienability of legal claims holds the promise of increasing access to justice and fostering development of the law. While much theoretical work points to this possibility, no empirical work has investigated the claims, largely due to the rarity of trading in legal claims in modern systems of law. In this paper we take the first step toward empirically testing some of these theoretical claims using data from Australia. We find some evidence that third-party funding corresponds to an increase in litigation and court caseloads. Cases with third-party funders are more prominent than comparable ones. While third-party funding may have effects on both the cases funded and the courts in jurisdictions where it is most heavily used, the overall welfare effects are ambiguous.
\end{abstract}

\section{TABLE OF CONTENTS}

INTRODUCTION 1076

I. BACKGROUND 1082

II. WHAT LITIGATION FUNDERS DO 1087

III. THEORY 1089

IV. DATA 1094

V. ANALYSIS 1097

VI. ROBUSTNESS AND INTERPRETATION 1104 CONCLUSION 1106

APPENDIX: DATA DEFINITIONS .1108

\footnotetext{
*Associate Professor of Law, Cleveland-Marshall College of Law. This Article benefitted from the helpful comments of numerous colleagues. In particular, I would like to thank Joel Topcik and Miranda Hunt. I also appreciate the outstanding research assistance of William Doyle, Megan Lewallen and Angela Krupar, and the financial support of the ClevelandMarshall Fund.
} 


\section{INTRODUCTION}

The primary argument for markets is that they increase overall welfare by allocating goods and services where they are most valued. ${ }^{1}$ Market forces can provide a powerful disciplinary effect on human behavior and the production of goods and services. Yet we don't see markets form everywhere. This paper deals with one missing marking in particular: the market for litigation.

Suppose we allow individuals the right to trade litigation claims, ${ }^{2}$ thereby creating a market for justice. This could be a market-based solution to the undersupply of some types of litigation. Would such a market spur innovation, increase settlement rates, and avoid taint? ${ }^{3}$

Selling litigation rights to parties with the resources to pursue the claims may address the problem of litigation undersupply due to credit constraints, risk aversion, collective action problems, or simply unawareness, even when a plaintiff or defendant has a positive expected payoff. A market for litigation should lead initially to more litigation, thereby clarifying disputes earlier. This could have large positive externalities, as future actors would have greater certainty about the law and therefore could make better-informed decisions. While government subsidies in the form of legal aid partially address these issues, ${ }^{4}$ a market for justice has the potential to have a much greater impact.

This paper makes the first attempt to quantify empirically the effects of a third-party litigation funding system. Using data from the leading Australian litigation-funding firm and Australian courts, we examine the impact of litigation funding on courts and on cases that receive funding.

1. See, e.g., Vicki Waye, Trading in Legal Claims: Law, Policy and Future DireCTIONS In AUSTRALIA, UK AND US 7 (2008) (discussing this argument).

2. We use the terms "litigation trading," "a market for litigation," and "third-party funding" interchangeably. Each term refers to the ability of individuals or firms with no direct interest in a particular claim to buy a fraction of that claim.

3. At a roundtable discussion session held at the conclusion of the 2010 UCLARAND Center for Law \& Public Policy on Third-Party Litigation Funding and Claim Funding, it was noted that the stigma associated with this legal practice is managed in nonU.S. jurisdictions through "institutional acceptance, leadership by members of the judiciary, and law firms that champion[ ] third-party funding in the absence of contingency-fee arrangements." Rand Institute For Civil Justice Program, Conference Proceedings, Third-PARTy Litigation Funding and Claim Transfer: Trends and IMPliCATIONS FOR THE Civil Justice System 23 (2010) [hereinafter Rand Institute Conference PROCEEDINGS], available at http://www.rand.org/content/dam/rand/pubs/conf_proceedings/2010/RAND_CF272.pdf.

4. See Earl Johnson, Jr., Justice for America's Poor in the Year 2020: Some Possibilities Based on Experiences Here and Abroad, 58 DePaul L. ReV. 393 (2009) (discussing public funding of legal services in the United States). 
The empirical strategy compares the outcomes in Australian states where litigation-funding firms are active to the outcomes in areas where they are not active.

Undersupply of litigation funding may result from several sources. Credit-constrained individuals or firms may have positive expected-value litigation claims, but be unable to pursue them due to lack of funds. ${ }^{5}$ Allowing third-party funders to buy a claim or a fraction thereof could allow a case to proceed where it would not have previously. ${ }^{6}$ The claims pursued with such financing would tend to be more costly and be brought by less-wealthy individuals or firms. ${ }^{7}$

Risk-averse individuals or firms will also eschew pursuit of positive expected-value claims, but not necessarily due to cost considerations. The uncertainty inherent in legal proceedings will reduce the value relative to a risk-neutral entity. ${ }^{8}$ Thus, the transfer of a claim from a risk-averse to a risk-neutral party should yield an increase in total claims pursued. The transferred claims would be riskier and be brought by more risk-averse entities. $^{9}$

There are other contexts in which third-party funding or litigation trading could affect the claims pursued. For example, multiple parties that share a claim in complex cases may face a collective action problem: while

5. See generally J. P. Gould, The Economics of Legal Conflicts, 2 J. LeGAL STUd. 279, 281 (1973) (developing a framework for "analyzing the problem of trading among individuals in the face of uncertainty"); James W. Huges \& Edward A. Snyder, Litigation and Settlement Under the English and American Rules: Theory and Evidence, 38 J.L. \& ECON. 225 (1995) (examining behavior under two different legal fee regimes); William M. Landes, An Economic Analysis of the Courts, 14 J.L. \& ECON. 61 (1971) (describing the economic theory for pre-trial settlement agreements); Richard A. Posner, An Economic Approach to Legal Procedure and Judicial Administration, 2 J. Legal STUD. 399 (1973) (explaining the procedural rules and practices that inform the legal-dispute resolution regime); George L. Priest \& Benjamin Klein, The Selection of Disputes for Litigation, 13 J. LEGAL STUD. 1 (1983) (developing a model of the litigation process that identifies the characteristics of suits that settle and suits that are litigated).

6. See Rand Institute Conference Proceedings, supra note 3, at 4 (noting that "[b]ecause the [litigation] process is so expensive, many with valid claims forgo litigation completely" and arguing that "[t]hird-party approaches to financing litigation . . . may encourage more parties to pursue their claims" and thereby "reduce the problem of unfiled claims.") .

7. See id. (arguing that litigation funding "could provide access to the courts for those who could otherwise not afford protracted litigation," while cautioning that "[f]inancing may not flow to those litigants who cannot afford to litigate.").

8. See Rand Institute Conference Proceedings, supra note 3, app. B at 122 ("Parties choosing between a certain outcome and an uncertain outcome [in litigation] will be guided by their risk preferences").

9. See Jonathan T. Molot, Litigation Finance: A Market Solution to a Procedural Problem, 99 Geo. L.J. 65, 84 (2010) [hereinafter Molot, Litigation Finance] (discussing risk-aversion affects bargaining positions of litigants). 
individually the case is not worth pursuing, it would be worth pursuing if all the benefits accrued to one party. ${ }^{10}$ Allowing the trading of claims makes it possible for this transfer of benefits to proceed.

One further group that could benefit from litigation trading consists of individuals and firms unaware that they possess a legal claim. If information about the legal system is imperfect, ${ }^{11}$ there will be entities that fall into this category. The ability of third parties to benefit in some way from the prospective resolution of claims creates an incentive to locate and provide information to otherwise unaware claim holders.

Litigation trading is not the only way to address the failure to pursue positive expected-value claims. In some legal systems, including the United States', contingency fees partially serve this purpose by lowering or eliminating entry costs for clients in addition to dispersing some of the risk of litigation. ${ }^{12}$ There are some important differences between contingency

10. See WAYE, supra note 1 , at 36 (citing Peter Charles Choharis, A Comprehensive Market Strategy for Tort Reform, 12 YALE J. ON REG. 435, 481 (1995)) (discussing Choharis' argument that extending the market for tort claims to allow investor involvement would increase access to justice, partially because it would overcome the collective action problem). Similar reasoning applies to the funding of class actions lawsuits. As some scholars have noted, however, the benefits of addressing the collective action problem must be weighed against the increased agency costs associated with adding layers between claims and the original claim holders. Janet Cooper Alexander, Do the Merits Matter? A Study of Settlements in Securities Class Actions, 43 Stan. L. Rev. 497, 534-48 (1991) (discussing conflicts of interest between attorneys and class action participants with regard to fee arrangements and settlement preferences); John C. Coffee, The Regulation of Entrepreneurial Litigation: Balancing Fairness and Efficiency in the Large Class Action, 54 U. CHI. L. REV. 877, 887-88 (1987) (examining potentially detrimental effects of entrepreneurial litigation on those represented by class counsel); David Friedman, More Justice for Less Money, 39 J. LAW \& ECON. 211 (1996) (suggesting alternative method for allocating damages in asbestos class action case); Jonathan R. Macey \& Geoffrey P. Miller, The Plaintiffs' Attorney's Role in Class Action and Derivative Litigation: Economic Analysis and Recommendations for Reform, 58 U. CHI. L. REV. 1, 12-27 (1991) (proposing auction in which attorneys bid opportunity to represent class, thereby restoring equilibrium between client and attorney interests).

11. Certainly the system of law schools, bar certification, and ongoing professional education requirements seems to indicate that knowledge of the law is a specialized skill. Thus, the notion that an individual without this specialized knowledge is unaware that he possesses a legal claim is entirely plausible. See Louis Kaplow \& Stephen Shavell, Legal Advice About Information to Present in Litigation: Its Effects and Social Desirability, 102 HARV. L. REV. 565, 576 (1989) (noting that "individuals[ ] [have] generally imperfect knowledge of the law and the legal system," in the context of deciding whether to present evidence to a tribunal in the absence of legal advice); see also WAYE, supra note 1, at 257 (discussing the motivation for third-party funders and attorneys operating under contingentfee arrangements to "identify[ ] potential claim holders and market[ ] their services to them").

12. 23 SAmuel Williston \& Richard A. Lord, A Treatise on the LaW of CONTRACTS $\S 62: 4,292-93$ (4th ed. $2002 \&$ Supp. 2011) (stating that one purpose of 
fees and litigation trading, however. The most prominent difference is that the potential funder in the contingency fee system must be an attorney. ${ }^{13}$ This can lead to some less desirable outcomes relative to litigation trading. For example, limiting potential funders to attorneys necessarily restricts the liquidity of the market for litigation, meaning that some positive expectation claims still may not be pursued because of an inability to find financing. It also may skew the claims that do get funded in favor of those that fit the risk profile of litigators. Many contingency-fee attorneys are unlikely to work on cases that have a low chance of success, even if the expected value is high. ${ }^{14}$ The contingency fee system also ends up imposing a large cost on clients, usually in the range of thirty percent-an amount that could be substantially decreased in a more competitive market for funding. ${ }^{15}$

At the introduction of a rule allowing litigation trading, one would expect an increase in initial legal claims from the credit-constrained, the risk-averse, and the previously ill-informed. ${ }^{16}$ Whether this would translate into an overall increase in litigation, however, is unclear. One would expect the introduction of a third-party funder to alleviate the problem of skewed settlements resulting from a risk-averse, one-off plaintiff engaging with a large defendant able to absorb and spread the cost. ${ }^{17}$ This would

contingent fee contracts is to allow plaintiffs access to legal services); Vince Morabito, Federal Class Actions, Contingency Fees, and the Rules Governing Litigation Costs 21 MonAsh U. L. REV. 231, 244 (1995) (stating that one of the benefits of contingency fees is that "they 'increase[e] access to justice by removing or reducing some of the costs [sic] disincentives that currently deter the initiation of legal proceedings"'); see also Molot, Litigation Finance, supra note 9, at 90 ("[C]ontingent fee arrangements transfer litigation risk from one-time plaintiffs, who are ill equipped to bear that risk, to attorneys who . . . can more easily bear the risk"). Insurance markets are another alternative method for addressing the misalignment of incentives for pursuing positive-value claims. See, e.g., Tom Baker \& Sean J. Griffith, Predicting Corporate Governance Risk: Evidence from the Directors' \& Officers' Liability Insurance Market, 74 U. CHI. L. REV. 487, 489 (2007) (discussing the transfer of corporate liability to insurance companies and noting that ownership of liability incentivizes insurance companies to "reintroduce[e] the deterrence function of corporate and securities law").

13. See Molot, Litigation Finance, supra note 9, at 91 (noting that "only lawyers are permitted to take a share of the plaintiff's claim under a contingent fee arrangement"). For a discussion of contingency fees and attorney behavior, see Lester Brickman, The Market for Contingent Fee-Financed Tort Litigation: Is It Price Competitive?, 25 CARDOZO L. Rev. 65 (2003).

14. Seth Lesser, Partner, Klafter Olsen \& Lesser LLP, Comments at RAND Litigation Finance Conference in Washington, D.C. (May 20, 2010) [hereinafter Seth Lesser Comments] (notes on file with authors).

15. WAYE, supra note 1, at 134.

16. See supra notes 5-11 and accompanying text (explaining this assumption).

17. See Molot, Litigation Finance, supra note 9, at 83-85 (discussing risk aversion, repeat litigants, and skewed settlements). 
lead to an increase in settlement rates as defendants adapted to the involvement of third-party funders. ${ }^{18}$

The overall welfare effects of introducing third-party funding into a legal system are also ambiguous. While benefits to several groups have been mentioned, they are not comprehensive. For example, an additional benefit of litigation trading may be clarification of the law. Should litigation trading increase, one would expect to not only see an increase in resources expended on litigation in general, but also a diversification of plaintiffs and claims. ${ }^{19}$ Consequently, previously unaddressed legal questions would arise and be resolved more quickly. This would lead to more efficient behaviors as parties make better-informed decisions.

There are also potential costs of allowing litigation trading. Legal prohibitions against maintenance, the practice of a party "without interest" in a suit assisting in litigation, and champerty, receiving a share of the proceeds of a suit, were intended to prevent the perversion of justice. ${ }^{20}$ The concerns voiced by courts over these early forms of third-party funding could plague modern litigation claim-trading systems as well. Another concern is that a rule change could lead to a vast increase in litigation with low social value, which would in turn congest the courts and divert their resources from more socially valuable litigation.

In this paper, we aim to add to the discussion of whether and to what extent third-party litigation funding should be available by providing the first empirical evidence relevant to these considerations. Effects on aggregate welfare are always difficult to measure convincingly, and we cannot do so directly here. This would require a great deal of detailed information on all manner of claims brought, most of which end in settlement. $^{21}$ Settlement data is notoriously difficult to collect, as its

18. Id.

19. See supra notes 4-9 and accompanying text (noting that litigation funding allows more risk adverse parties to bring claims and for more complex claims to be brought).

20. Our definitions of maintenance and champerty are derived from Shukaitis. Marc J. Shukaitis, A Market in Personal Injury Tort Claims, 16 J. Legal STUd. 329, 330 n.1 (1987); see also Rancman v. Interim Settlement Funding Corp., 789 N.E.2d 217, 219-20 (2003) (quoting Key v. Vattier, 1 Ohio 132, 143 (1823) in characterizing maintenance as "an offense against public justice," which "perverts the remedial process of the law into an engine of oppression" and noting that "[t]he ancient practices of champerty and maintenance have been vilified"). For more information about the history of maintenance and champerty in Australia, see infra notes 29-39 and accompanying text.

21. While settlement rates vary by location and nature of claim, settlement in civil trials has been estimated to be as high as ninety-five percent. See, e.g., Marc Galanter \& Mia Cahill, "Most Cases Settle": Judicial Promotion and Regulation of Settlements, 46 STAN. L. REV. 1339, 1339-40 (1994) (citing frequently quoted figures that settlement rates are between eighty-five and ninety-five percent, but cautioning that these figures may be misleading); see also Cooper Alexander, supra note 10, at 498 (noting that "only a tiny 
reporting is not required except in very limited circumstances. ${ }^{22}$ However, by empirically examining the first major implementation of a third-party funding system, we are able to shed some light on the central questions.

Specifically, we collect data from Australian courts, administrative agencies, and the largest third-party litigation funding firm in Australia, IMF (Australia) Ltd. ${ }^{23}$ Using this data, we take two approaches to understanding the impact of third-party funding on various outcomes. First, we use IMF's entry into an Australian state as a proxy for the relaxing of rules against third-party funders. Using court data, we can examine the effects of the rule change on the processing and expense of litigation in the courts. We attempt to control for overall time trends and state-specific differences by using criminal data as a control, since thirdparty funding is only available in civil litigation. We find that third-party funding does appear to be associated with increased expense to the courts, an increased backlog, and an increase in average case duration. ${ }^{24}$

Second, we use a case study methodology to examine a handful of published cases considered by IMF, some of which were funded and some of which were not. By examining all cases considered by IMF and not just funded cases, we attempt to eliminate some of the selection bias inherent in the process of choosing cases for funding. ${ }^{25}$ Here, we find a difference in the impact of cases that were funded from those that were not. The funded cases cite substantially more cases than unfunded ones, and are themselves cited over twice as frequently. This evidence supports the notion that thirdparty funding can spur the development of law.

The past several years have seen a major downturn in the market for legal services. ${ }^{26}$ New technologies are allowing the outsourcing of more legal matters, and firms are becoming increasingly global. ${ }^{27}$ As such, many

fraction of litigated cases - perhaps five percent or less - are actually tried to judgment").

22. See Robert G. Bone, Modeling Frivolous Suits, 145 U. PA. L. REV. 519, 528 (1997) (explaining that "researchers cannot easily obtain settlement data because parties often keep settlements confidential, making it very difficult to test... the most serious effects of frivolous litigation").

23. The Australian firm IMF (www.imf.co.au) is not to be confused with the International Monetary Fund.

24. See infra pt. 0.

25. Of course, we cannot eliminate the selection effect completely, because even within the group of considered cases, there may be some unobservable characteristics that affected the ones that were picked for funding. But using the considered cases as the universe should at least mitigate the effect.

26. See Eli Wald, Foreword: The Great Recession and the Legal Profession, 78 FordHAM L. REV. 2051 (2010) (discussing the recent downturn in the legal services market).

27. See Milton C. Regan, Jr. \& Palmer T. Heenan, Supply Chains and Porous Boundaries: The Disaggregation of Legal Services, 78 FoRDHAM L. REV. 2137, 2138-42 
countries around the world are reconsidering restrictions on various legal practices that would allow for, among other things, law firms to be publicly traded, firms to take on non-attorney partners, and litigation to be funded by third parties. ${ }^{28}$ In this paper, we hope to add some empirical evidence to help inform policy discussions in the last category.

The remainder of this paper is organized as follows. First, we provide some of the history behind prohibitions on third party funding and its evolution, and then discuss in detail how litigation funding works in Australia. We then introduce a new model of the potential impact of litigation funding. Next, we present empirical specifications and data sources, followed by our main empirical results. This is followed by an exploration of the limitations of these findings, and then concluding remarks.

\section{BACKGROUND}

Prohibitions on third-party involvement in litigation have a medieval origin. $^{29}$ During this era in England, coercive litigation was used by wealthy landowners as a means to obtain more land. ${ }^{30}$ This often took the form of funding litigation by third parties with the express goal of acquiring more land at below-market prices. ${ }^{31}$ This eventually led to a response by the legislature, which passed a number of statutes that included prohibitions on maintenance and champerty. ${ }^{32}$

These prohibitions remained in effect in several common law jurisdictions through today. ${ }^{33}$ As legal systems have become more

(2010) (describing the trend towards outsourcing legal services).

28. See Marco de Morpurgo, A Comparative Legal \& Economic Approach to ThirdParty Litigation Funding, 19 CARDOZO J. INT'L \& COMP. L. 343, 345-46 (2011) (comparing various legal systems and third-party funding).

29. Waye, supra note 1, at 12 (citing Jeremy Bentham, The Works of Jeremy Bentham 19 (John Bowring ed., 1843); Max Radin, Maintenance by Champtery, 24 CAL. L. REV. 48, 57-62 (1935); and Percy H. Winfield, The History of Maintenance and Champerty, 35 L. Q. REV. 50, 51 (1919)).

30. WAYE, supra note 1, at 12-13; see also Andrew Hananel \& David Staubitz, The Ethics of Law Loans in the Post-Rancman Era, 17 Geo. J. Legal Ethics 795, 797 (2004) (" $\mathrm{t}] \mathrm{che}$ common law maintenance doctrine developed in feudal England in response to the practice of feudal lords of maintaining all of their retainers' lawsuits in order to enlarge their estates.").

31. WAYE, supra note 1, at 12.

32. WAYE, supra note 1, at 13-14.

33. The United States still permits litigants to advance the theories of maintenance and champerty to challenge the validity of contracts, though those theories are rarely used in practice. See Jason Lyon, Revolution in Progress; Third-Party Funding of American Litigation, 58 UCLA L. REv. 571, 584-87 (2010) (providing a brief history of American courts' attitudes towards third-party funding). 
formalized and less prone to outside corruption, the rationale for these doctrines has waned. Many jurisdictions have abolished maintenance and champerty as torts ${ }^{34}$ and England abandoned them in 1967 with the Criminal Law Act. $^{35}$ In Australia a number of states have abolished prohibitions on maintenance and champerty, including New South Wales, Australian Capital Territory, Victoria, and South Australia. ${ }^{36}$ In the United States, although there have been few prosecutions for maintenance or champerty in the last century, ${ }^{37}$ the legal theories underlying the doctrines are still considered valid. ${ }^{38}$ In recent years, Australia has abandoned prohibitions on champerty and maintenance. ${ }^{39}$

Third-party litigation funding provides financial support for litigation by an entity that is not a party to the litigation and with no direct interest in the outcome. It is therefore a direct violation of the doctrine of maintenance. Historically, third-party litigation funding has been tolerated in some contexts, such as the disposition by liquidators ${ }^{40}$ or trustees ${ }^{41}$ in

34. WAYE, supra note 1 , at 14.

35. WAYE, supra note 1, at 14 (citing Criminal Law Act, 1967, c. 58, §§ 13, 14 (U.K.)).

36. Waye, supra note 1, at 14 (citing Law Reform (Miscellaneous Provisions) Act 1955 (ACT) s 68 (Austl.) as amended by Civil Law (Wrongs) Act 2002 (ACT) s 221 (Austl.); Maintenance, Champerty and Barratry Abolition Act (No 88) 1993 (NSW) (Austl.); Criminal Law Consolidation Act 1935 (SA) sch 11 ss 1(3), 3(1) (Austl.); Crimes Act 1958 (Vic) s 322A (Austl.); Wrongs Act 1958 (Vic) s 32 (Austl.)). Even though criminal sanctions were abolished for maintenance and champerty, the common law ability to reject such contracts for public policy reasons remains. Overall, however, and in all districts, such contracts are usually enforceable. WAYE, supra note 1 , at 15.

37. See Waye, supra note 1, at 14-15 ("Only a handful of cases have applied maintenance and champerty as torts in the United States in the last one hundred years."); Hananel \& Staubitz, supra note 30, at 801-04 (comparing approaches to maintenance and champerty in United States jurisdictions); Susan Lorde Martin, Financing Litigation Online: Usury and Other Obstacles, 1 DePAul Bus. \& COM. L.J. 85, 87-89 (2002) (examining state approaches to champerty); Susan Lorde Martin, The Litigation Financing Industry: The Wild West of Finance Should Be Tamed not Outlawed, 10 FordHAM J. CORP. \& Fin. L. $55,57-58$ (2004) (" $[\mathrm{I}] \mathrm{n}$ the United States, even in states that have maintained the prohibition against champerty in general, there have always been exceptions to the prohibition.").

38. See WAYE, supra note 1, at 14-15 ("[C]hamperty and maintenance continue to survive as rules of public policy . . ."); Lyon, supra note 33, at 584 ("Champtery and maintenance still rear their heads in American courts. Though raised infrequently, they retain currency, at least in some jurisdictions."); Paul Bond, Comment, Making Champerty Work: An Invitation to State Action, 150 U. PA. L. REV. 1297, 1298 (2002) (“[C]hamperty's critics underestimate the continuing vitality of the doctrine.").

39. England, like Australia, has also abolished maintenance and champerty as torts and offenses. WAYE, supra note 1, at 14; see also George R. Barker, Third-Party Litigation Funding in Australia and Europe, 8 J.L. ECON. \& POL'Y 451, 493-94 (2012) (discussing the abolition of maintenance and champerty as offenses in the U.K. and Australia).

40. See WAYE, supra note 1 , at 57 (citing cases involving disposition by liquidators) (citing In re Park Gate Waggon Works Co. (1881) 17 Ch. 234 (Eng.) (disposition by liquidator); Re Movitor Pty Ltd (1996) 64 FCR 380 (Austl.) (disposition by liquidator); 
bankruptcy of an insolvent's causes of action. ${ }^{42}$ In Australia, the scope of litigation funding has recently expanded with the emergence of funders who support general commercial litigation with no interest other than potential return on an investment. ${ }^{43}$ Third parties usually agree to fund litigation in exchange for a fraction of any amount recovered in the litigation, plus any reimbursed costs ordered. Litigation funding is used in bankruptcy proceedings, breach of contract suits, and class action lawsuits. ${ }^{44}$

The change in Australia has been due partly to the gradual abolition of maintenance and champerty, which made it legal for funders to begin operations. Most Australian third-party funders in the 1980's and 1990's operated in the area of bankruptcy, historically an area in which the law was relatively clear about the legality of the third party funding. ${ }^{45}$ Funders began operating to a limited extent in other areas in the late 1990s and 2000s, but did not expand rapidly because there was still substantial uncertainty about the legality of their ventures. It was not until the landmark Fostif decision in 2006 that the law regarding third-party funding was truly clarified. ${ }^{46}$

Fostif arose from a previous decision, Roxborough v. Rothmans of Pall Mall Ltd., ${ }^{47}$ concerning payments to tobacco retailers by tobacco wholesalers. The Fostif proceedings were initiated, organized, and funded by an outside company, Firmstone Pty Ltd.; on appeal, Australia's highest court took up the issue of the legality of the payment arrangement between

UTSA Pty Ltd v Ultra Tune Australia (1998) 146 FLR 209 (Austl.) (disposition by liquidator); Re Tosich Constr. Pty Ltd (1997) 73 FCR 219 (Austl.) (disposition by liquidator); Re William Felton \& Co Pty Ltd (1998) 145 FLR 211 (Austl.) (disposition by liquidator)).(noting that this statutory exception only applies to property of the company. See Re Fresjac Pty Ltd (1995) 65 SASR 334 (Austl.)).

41. See WAYE, supra note 1, at 57 (citing cases involving disposition by a trustee) (citing Seear v Lawson (1880) 15 Ch D 729 (Eng.) (disposition by trustee); Guy v. Churchill (1888) 40 Ch D 481 (Eng.) (disposition by trustee); Re Nguyen, Ex parte Official Trustee in Bankruptcy (1992) 35 FCR 320 (disposition by trustee); Re Cirillo, Ex parte Offficial Trustee in Bankruptcy (1996) 65 FCR 576 (disposition by trustee)).

42. See Interview with John Walker, Managing Director, IMF, (Australia) LTD (July 16,2008 ) (interview notes on file with authors) (giving a brief overview of the history of maintence and champerty in Australia and third-party litigation funding) . See also Hugh McLernon, In Support of Professional Litigation Funding 37-39 (IMF (Austl.) Ltd Litig. Funding Working Paper, 2005) (discussing the history of third-party litigation funding).

43. WAYE, supra note 1, at 58-63.

44. See WAYE, supra note 1, at 55; see also Laurie Glanfield, Litigation funding in Australia, Standing Committee of Attorneys-General Discussion Paper (2006) (describing the legal context of litigation funding).

45. Interview with John Walker, supra note 42.

46. Campbells Cash \& Carry Pty Ltd. v. Fostif Pty Ltd. (2006) 229 CLR 386 (Austl.).

47. Roxborough v. Rothmans of Pall Mall Ltd., (2001) 208 CLR 516 (Austl.). 
the parties. ${ }^{48}$ Firmstone had signed agreements with over two thousand plaintiffs in connection with the damage recovery. The agreements included provisions that Firmstone would receive any litigation costs awarded to the plaintiffs plus one-third of the payments recovered from the wholesalers. ${ }^{49}$ Firmstone would also pay all litigation and other associated costs and would arrange for counsel if litigation was necessary. ${ }^{50}$

The high court addressed the legality of Firmstone's arrangement with plaintiffs from two angles, asking (1) whether the actions of Firmstone constituted an abuse of process and (2) whether allowing it was counter to public policy. The court determined that the mere action of litigation funding by a third party was not an abuse of process. ${ }^{51}$ It further found that, in jurisdictions where maintenance and champerty had been abolished, third-party litigation could not be counter to public policy. ${ }^{52}$ By so holding, the Court solidified the footing of third-party funding in Australia. ${ }^{53}$

The Fostif decision occurred in the context of growing demand for litigation funding in Australia. In recent decades, the Australian population has increasingly looked to the legal system to determine social policy, as well as individual rights and duties. ${ }^{54}$ In concert with the court's increased presence in daily interactions, Australians have also demanded greater access to the judicial system. ${ }^{55}$ This general demand for access has been met by allowing third-party funders to both participate in, and, to a certain extent create, the market for legal claims.

Earlier court decisions had articulated a narrow range of situations in which claims assignment could be employed. For example, as early as 1908, courts permitted the transfer of claims in situations in which the

48. Fostif, (2006) 229 CLR 386

49. Id. at 477.

50. WAYE, supra note 1, at 236.

51. Fostif, (2006) 229 CLR at 436.

52. Id. at 432-435.

53. See WAYE, supra note 1, at 55 (noting that the Australian High Court effectively authorized litigation funding in its Fostif ruling, but cautioning that "Australian jurisprudence certainly stops well short of allowing full claim alienability and directly rejects the commodification of legal claims"); Michael Legg et al., Litigation Funding in Australia 2 (Univ. of N.S.W. Faculty of Law Research Series, Working Paper No. 12, 2010), available at http://papers.ssrn.com/sol3/papers.cfm?abstract_id=1579487 ("Since the High Court gave its ruling in Campbells Cash and Carry Pty Limited v Fostif Pty Ltd, the Australian litigation funding industry has enjoyed significant growth.").

54. See WAYE, supra note 1, at 58 (citing Sir Anthony Mason, Law and Morality, 4 GRIFFITH L. REV. 147, 148-51 (1995) (commenting that the decline of religion, the extended family unit, and the disintegration of old social and economic conventions and standards have accentuated the importance of law in society and generated the expectation that the law will provide resolutions to pressing political and social problems)).

55. WAYE, supra note 1 , at 58. 
funder had a legitimate interest in the result of the lawsuit. ${ }^{56}$ This legitimate interest requirement could be met where the parties were related by blood and in employer-employee relationships. ${ }^{57}$ Likewise, an association established to protect the legal interests of its membership was also considered to have a legitimate interest. ${ }^{58}$ The funders were also required to demonstrate that they neither planned to "on-sell" the claim nor "wager" on the outcome of the litigation.

Funders that possess a "legitimate commercial interest[ ] in the outcome of a dispute also fall outside the prohibition against assignment of a bare cause of action." 60 Such an interest "might arise out of a charge over the assets and undertaking of the funded party's property," or ${ }^{61}$ could exist where the funder claimed a right to "commission under disputed contracts." ${ }^{\circ 2}$ Courts characterized some interests as mere hopes, and declined to permit a funder's intervention in situations in which the funder's commercial interest was contingent upon a favorable outcome in the litigation. ${ }^{63}$ A "hope" of a commercial interest does not amount to a recognizable commercial interest.

In situations involving a bankrupt claim holder, the courts have permitted a broader definition of legitimate interest. ${ }^{64}$ In bankruptcy, the bankrupt entity assigns its legal claims to the trustee, thereby allowing the trustee to pursue the matters in court. ${ }^{65}$ The bankruptcy exception to the

56. WAYE, supra note 1, at 58 (citing British Cash \& Parcel Conveyors Ltd v Lamson Store Svc. Co Ltd [1908] 1 KB 1006 (Eng.)).

57. Id. (employing the legitimate interest requirement)).

58. See WAYE, supra note 1, at 58 (citing Martell v Consett Iron Co Ltd [1955] Ch 363 (Eng.) (unincorporated association); Magic Menu Sys. Pty Ltd v AFA Facilitation Pty Ltd (1996) 72 FCR 261 (Austl.) (franchise); Moloney v Housing Indus. Ass'n Ltd (Unreported, Tas SC Dec. 4, 1992) (Austl.) (trade association)).

59. See WAYE, supra note 1, at 58 (citing S. Australian Asset Mgmt. Corp. v Sheahan (1995) 13 ACLC 328 (Austl.); JC Scott Constrs. Pty Ltd v Mermaid Waters Tavern Pty Ltd [1982] 2 Qd.R. 413 (Austl.); Re Movitor Pty Ltd (1996) 64 FCR 380 (Austl.); Trendtex Trading Corp. v. Credit Suisse [1982] A.C. 679 (Eng.); Giles v. Thompson [1994] 1 A.C. 142,146 (U.K.)).

60. Waye, supra note 1, at 58.

61. See WAYE, supra note 1 , at 58 (citing Vangale Pty Ltd v Kumagai Gumi Co Ltd [2002] QSC 137 (Austl.)).

62. Id.

63. See WAYE, supra note 1, at 58-59 (citing Project 28 Pty Ltd (formerly Narui Gold Coast Pty Ltd) v Barr, [2005] NSWCA 240 (Austl.)).

64. See WAYE, supra note 1, at 59 (citing Stevens v Keogh (1946) 72 CLR 1, 2 (Austl.) (holding that funding by the Police Association of New South Wales of an action brought by an insolvent member was not maintenance)).

65. In re Tomaiolo, 205 B.R. 10 (Bankr. D. Mass. 1997) (legal malpractice claims were property of estate and trustee therefore had right to pursue those claims);. But see Christison v. Jones, 405 N.E.2d 8 (Bankr. Ill. App. 3d 1980) (holding that a legal malpractice claim is not part of the bankrupt's estate because it is not subject to assignment). 
prohibition against transfer of claims is justified for two reasons. First, liquidators, receivers, and trustees in bankruptcy owe fiduciary duties to the entity's creditors and debtors alike; thus, the interests of the parties are aligned despite the lack of a traditionally conceived "legitimate interest" in the disposition of claims. ${ }^{66}$ They act as officers of the court and are obligated to perform their role, within the boundaries of the respective statutory provisions, to satisfy the interests of the creditors. Second, the trustee who fails to fulfill his or her duties to "close [the bankrupt entity's] estate ... as expeditiously as is compatible with the best interests of parties in interest" ${ }^{\prime 67}$ may risk loss of fees and/or prosecution, both civil and criminal. $^{68}$

In general, Australian courts now appear to welcome litigation funding. According to QPSX Ltd v Ericcson Australia Pty Ltd., the exercise of due diligence and formulation of budgets by firms like IMF injects "a welcome element of commercial objectivity into the way in which such [complex commercial litigation] budgets are framed and the efficiency with which the litigation is conducted." ${ }^{\prime 9}$

\section{WHAT LITIGATION FUNDERS DO}

Litigation funding firms provide references, expertise, and most importantly, capital, to third parties pursuing legal claims. ${ }^{70}$ In exchange, the funders receive a portion of the proceeds of any settlement or award at trial. While these firms could purchase the entire payoff from a claim, this would create a principal-agent problem. In most cases, the cooperation of the original claim holder is essential to successfully prosecuting a claim, ${ }^{71}$

66. See In re WHET, Inc., 750 F.2d 149 (1st Cir. 1984) (a trustee in bankruptcy "owes a fiduciary duty to debtor and creditors alike to act fairly and protect their interests"); In re Rigden, 795 F.2d 727, 729 (9th Cir. 1986) ("The trustee . . . has a fiduciary obligation to conserve the assets of the estate and to maximize distribution to creditors."); In re Heinsohn, 247 B.R. 237, 244 (E.D. Tenn. 2000) ("A bankruptcy trustee is a fiduciary of the estate, its beneficiaries and the creditors.").

67. 11 U.S.C. $\$ 704$ (a) (2006).

68. See, e.g., In re Hutchinson, 5 F.3d 750 (Bankr. 4th Cir. 1993) (discussing the source of trustee liabilities as Mosser v. Darrow, 341 U.S. 267 (1951)); In re NWFX, Inc., 384 B.R. 214 (Bankr. W.D. Ark. 2008) (ordering disgorgement of trustee's fees after it was discovered that trustee made certain misrepresentations regarding the proposed settlement).

69. QPSX Ltd v Ericsson Australia Pty Ltd (2005) 219 ALR 1 (Austl.).

70. See Waye, supra note 1, at 41-45 (describing the relationship between litigation funding firms and claim holders).

71. See Shukaitis, supra note 20, at 340-41 (discussing how to incentivize the original claim holder to participate in litigation); George Steven Swan, Economics and the Litigation Funding Industry: How Much Justice Can you Afford?, 35 New ENG. L ReV. 805, 819-20 (2001) (noting that successful recovery in a suit may depend on the cooperation of the tort 
and the best way to ensure this cooperation is by leaving the original claim holder holding a substantial portion of the claim to ensure the original claim holder's future cooperation. Thus, in practice, litigation funding firms tend to hold between thirty and sixty percent of the claim. ${ }^{72}$

At present, litigation funding firms tend not to be "interested in funding personal injury claims involving physical or mental injury to individuals that rely heavily on oral testimony and witness credibility because of the greater risks associated with these claims." "prefer commercial claims where the primary evidence is documentary.". ${ }^{74}$ Firms also tend to set minimum values for claims; for example, one firm does not fund cases below seven hundred fifty thousand Australian dollars in value, while another firm wants a stake of at least one to two million Australian dollars. ${ }^{75}$

Firms fund cases where the risk is small and where they estimate the probability of winning a successful judgment or settlement to be large. At one firm, the probability of succeeding by judgment or settlement must be greater than ninety-five percent, while at another, the required probability of success is fifty percent. ${ }^{76}$ Firms prefer cases that are likely to settle quickly, because the longer and more complex a matter is, the greater the firm's risk. ${ }^{77}$ Litigation funding firms also thoroughly investigate the claim holder, especially if the claim holder is to be a key witness in the case. ${ }^{78}$

Claim owners must provide detailed information to the third-party funder prior to concluding the funding contract. The funder then uses the information to conduct a risk analysis. If the funder's exposure to risk is small, then the funder may make an offer of funding without further inquiry. However, if the risks are high, the funder does due diligence on the claim. ${ }^{79}$ During this process, the funder will evaluate the claim amount, verify the liquidity of the defendant(s), obtain fee estimates for legal and other expert advice, and seek counsel's opinion regarding the likely success of the claim. Throughout this process, the funder retains the right to terminate the financing arrangement if new evidence emerges which

victim).

72. Interview with John Walker, supra note 42; see also Legg, supra note 54 (providing examples of funding agreement provisions in which the funding firm receives only a portion of a judgment or settlement recovery).

73. WAYE, supra note 1, at 282-83.

74. Interview with John Walker, supra note 42.

75. WAYE, supra note 1, at 282-83.

76. Id.

77. Id.

78. Id.

79. Id. at 41 . 
negatively impacts upon the chances of a successful outcome. ${ }^{80}$

Once funders become involved, their role within the litigation environment can vary. Some firms essentially act as a banker. Although they monitor the prosecution of the claim by the claim holder's lawyers and ensure compliance with budget caps, they do not participate in the day-today management of the claim nor do they provide instructions to the claim holder's lawyers. ${ }^{81}$ While funders do engage in informal communication with the claim holders, they need not formally report to the client. ${ }^{82}$ Although firms differ on this policy, some firms do not exercise veto rights over whether a claim holder accepts or declines a settlement offer. ${ }^{83}$

One firm requires the lawyers to report regularly, but it is not active in the control of strategy or in the management of litigation. The firm's main concern is that the claim is progressing within an agreed-upon budget. ${ }^{84} \mathrm{It}$ sets a global budget for legal services and the lawyers then determine how to "prosecute the claim within that budget;" however, it does not control the budget on a line-item basis. ${ }^{85}$

Other firms are even more active and monitor and advise throughout the process. ${ }^{86}$ The funder may cap lawyers' fees and establish clear timelines to align budget and strategy. ${ }^{87}$ Any settlement proposal must be a joint decision between the funding firm and the claim holder. In no case do the firms "have a fiduciary duty to the client," and instead see their "position as analogous to insurers," and only owe a "duty of good faith to the client." $\$ 8$

\section{THEORY}

Economic theory is ambiguous as to the effects of litigation funding. While there have been several excellent theoretical discussions on the topic ${ }^{89}$ there has been little formal work and no empirical work conducted

80. Id. at 41 .

81. Id. at $286-87$.

82. Id. at $287-88$.

83. Id. at $284-85$.

84. Id. at 286

85. Id. .

86. Id. at $286-87$

87. Id.

88. Id. at 284-86.

89. See, e.g., Michael Abramowicz, On the Alienability of Legal Claims, 114 YALE L.J. 697 (2005) (considering the normative question of whether legal claims should be alienable); Robert Cooter, Towards a Market in Unmatured Tort Claims, 75 VA. L. REv. 383 (1989) [hereinafter Cooter, Towards a Market] (developing a model for unmatured tort claims in light of economic theory); Mariel Rodak, It's About Time: A Systems Thinking Analysis of the Litigation Finance Industry and Its Effect on Settlement, 155 U. PENN. L. 
to date. Below, we outline a simple model of litigation trading, but we first summarize some of the predictions from the theoretical literature.

Shukaitis (1987) suggests that litigation trading could increase the value of compensation to claimants and increase deterrence for a host of activities. ${ }^{90}$ It could also lead to more nuisance suits and a greater volume and duration of litigation. ${ }^{91}$ Litigation funding promotes claims brought by indigent and risk-averse victims that would not otherwise be pursued. ${ }^{92}$

Abramowicz (2005) maintains that litigation trading will lead to an increase in cases that are weak on the merits, but that plaintiffs manage to "puff up" by misrepresenting the particulars to a litigation funding company. Potential claims sellers will have an incentive to overstate their claims to potential buyers, thereby creating an adverse selection problem. ${ }^{93}$ The third-party buyers have worse information about the claim than either the plaintiff or the defendant. Thus, only claims that do not settle are likely to be offered on the claims market. ${ }^{94}$

Abramowicz predicts litigation funding will cause an increase in cases being pursued in jurisdictions where damage awards are more unpredictable. ${ }^{95}$ In such areas, risk-averse plaintiffs will prefer a small, sure recovery to a large, uncertain recovery. As a larger entity with deeper pockets, the litigation funder is able to act in a risk-neutral way. In one scenario Abramowicz posits, litigation funding companies will over-litigate (even at a loss) to create fearful reputations in the short-run, thereby facilitating easier settlements in the future. ${ }^{96}$ Litigation funders will prefer a long-term strategy whereby most cases settle, because this would be the least costly method of maximizing profits. ${ }^{97}$

The qualitative literature predicts that under a litigation funding regime, claimants will recover the claim amount sooner and could minimize their own risk by selling to a risk-neutral third party. The thirdparty funders consolidate and accelerate cases because they can pool similar claims and act as repeat players.

Thus far, the literature discussed has considered ex post trading in litigation claims; that is, claims for which the harm has already occurred.

REV. 503 (2006) (applying systems thinking to litigation finance).

90. Shukaitis, supra note 20, at 334-41.

91. Id. at 342-46.

92. See id. at 338 ("Given their expected risk averseness, poorer tort victims may be especially dissuaded from pursuing valid claims because of the costs involved.").

93. Abramowicz, supra note 89 , at 743-45.

94. Id. at 744-45; Shukaitis, supra note 20, at 344.

95. Abramowicz, supra note 89 , at 735-37, 740-41.

96. Id. at 728 .

97. See id. at 728-29 (analogizing litigation funders to insurance companies, which often settle cases). . 
In a pair of fascinating papers, Robert Cooter considers a closely related topic: a market in unmatured claims. ${ }^{98}$ Cooter proposes a market in which individuals could make ex ante sales of litigation claims, even before any harm occurs. For example, individuals with health insurance may want to sell the right to sue for a workplace injury, knowing that health expenses would almost certainly be covered by insurance. ${ }^{99}$ While related to a market for third-party litigation funding ex post, Cooter's idea has yet to be implemented.

In Litigation Finance: A Market Solution to a Procedural Problem, Molot considers the shortcomings of the predominance of settlement in the current disposal of most litigation. ${ }^{100}$ Parties to a settlement may have very different time or risk preferences, but settlements may differ substantially from those to which risk-neutral parties would agree. A market for litigation claims would allow risk-neutral parties to negotiate settlements (or litigate) with outcomes that better reflect the strength of cases and the law. Molot considers a related topic in A Market in Litigation Risk, ${ }^{101}$ a paper that is closer to Cooter's (1988) and Cooter and Sugarman's (1989) work in considering the effects of trading ex ante litigation claims. In contrast, the focus of our paper is on trading or funding of ex post claims.

In order to be more precise about the expected effects of litigation trading on a market for litigation claims, we formally model the litigation process of a risk-averse claimant. Suppose a plaintiff bringing a suit has two possible outcomes, a gain of $A$ or 0 , with probabilities $p$ and (1-p), respectively. The cost of bringing the suit is $C$. A risk-neutral individual pursues the suit if its expected value is greater than the cost; mathematically, this suit will be pursued if $p A>C$. If the individual is risk-averse, we can describe the individual as one who only pursues cases with a positive certainty equivalent. To be concrete, assume the following utility function over gambles:

$\mathrm{U}=\mathrm{E}(\mathrm{r})-0.005 \mathrm{R} \sigma^{2}$, where $R$ denotes the risk aversion parameter and the utility function is calibrated so that everything is measured in percent. ${ }^{102}$ In terms of return, the gamble is between a gain of $\left(\frac{A-C}{C}\right)$ and a loss of $100 \%$ :

98. Robert Cooter \& Stephen D. Sugarman, A Regulated Market in Unmatured Tort Claims: Tort Reform by Contract, in New Directions In LiabiLity LAW 174 (W. Olsen ed., 1988); Cooter, Towards a Market, supra note 89.

99. In a later paper, Cooter labels such a system "anti-insurance." Robert Cooter \& Ariel Porat, Anti-Insurance, 31 J. LEgAL STUD. 203 (2002)

100. Molot, Litigation Finance, supra note 9.

101. Jonathan T. Molot, A Market in Litigation Risk, 76 U. CHI. L. REv. 367 (2009).

102. This type of utility function is sometimes used in finance for illustrative purposes. While it is clearly unrealistic for some values, it is chosen here because of its analytical 


$$
\begin{aligned}
& \left(\frac{A-C}{C}\right) 100=\left(\frac{A}{C}-1\right) 100 \\
& \left(\frac{-C}{C}\right) 100=-100
\end{aligned}
$$

The expected return is straightforward to calculate:

$$
\begin{aligned}
& E(r)=p\left(\frac{A}{C}-1\right) 100+(1-p)(-100) \\
& =100\left(\frac{p A}{C}-p+p-1\right)=100\left(\frac{p A}{C}-1\right)
\end{aligned}
$$

We can also calculate how much uncertainty there is to the plaintiff, as measured by the variance of the return. Since there are only two possible outcomes, this simply requires calculating the variance for an uncertain event with binary outcomes, as follows:

$$
\begin{gathered}
\sigma^{2}(r)=p\left[100\left(\frac{A}{C}-1\right)-100\left(\frac{p A}{C}-1\right)\right]^{2} \\
+(1-p)\left[-100-100\left(\frac{p A}{C}-1\right)\right]^{2} \\
\frac{\sigma^{2}}{10^{4}}=p\left(\frac{A-C-p A+C}{C}\right)^{2}+(1-p)\left(\frac{-C-p A+C}{C}\right)^{2} \\
\frac{\sigma^{2}}{10^{4}}=p\left[\frac{A(1-p)}{C}\right]^{2}+(1-p)\left(\frac{-p A}{C}\right)^{2} \\
\frac{\sigma^{2} C^{2}}{10^{4} A^{2}}=p(1-p)^{2}+(1-p) p^{2} \\
\frac{\sigma^{2} C^{2}}{10^{4} A^{2}}=p(1-p)[(1-p)+p]=p(1-p)
\end{gathered}
$$

Which simplifies to: 


$$
\sigma^{2}=\frac{10^{4} A^{2}}{C^{2}} p(1-p)
$$

Now we return to the plaintiff's utility function and plug in for $E(r)$ and

$$
U=E(r)-.005 R \sigma^{2}
$$

and determine when this will have a positive value:

$$
\begin{gathered}
=100\left(\frac{p A}{C}-1\right)-.005 R\left[\frac{10^{4} A^{2}}{C^{2}} p(1-p)\right]>0 \\
=2 p A-2 C-R \frac{A^{2}}{C} p(1-p)>0
\end{gathered}
$$

Now this function can be examined or plotted to help understand the comparative statics. We can hold all other parameters fixed and take the derivative of $p$ with respect to $R$ or $C$. A decrease in $R$ (the risk aversion parameter) will lead to a decrease in $p$. This illustrates that risk-neutral entities (like third-party funders) are willing to litigate cases with a lower probability of return.

The results for litigation costs, $C$, are a bit more complicated. For most reasonable values of $C$, higher litigation costs will lead to a requirement of a higher $p$ : individuals litigate cases with a higher probability of success. This illustrates the theory that if litigation funding allows the smoothing of risk and the relaxing of credit constraints (and hence lowering of costs), individuals will litigate cases with a lower probability of a successful outcome and the number of suits may rise.

One limitation of this model, however, is that the probability $p$ of winning a lawsuit is exogenous to litigation funding. But litigation funding could increase the probability of winning a lawsuit. For example, litigation funding may help in the discovery process. Larger, more complex lawsuits could arise and lawsuit quality could be endogenous to litigation funding. ${ }^{103}$

103. On the other hand, litigation funding could decrease the amount of damages awarded if the court knows that the damages awarded are going to a third party. 


\section{DATA}

The empirics we present draw upon data from three main sources. First, we have personally been in contact with the largest litigation funding firm, IMF (Australia) Ltd, which has captured over half of the market share in Australia. ${ }^{104}$ IMF has provided a list of lawsuits that it has funded as well as a list of lawsuits considered but not funded. The data from the lawsuits funded includes opening and closing dates, monthly profit and loss, expenditures, return on investment, case classification, and case location. ${ }^{105}$

Figure 1. Distribution of Case Duration of Cases Funded by IMF (Days)

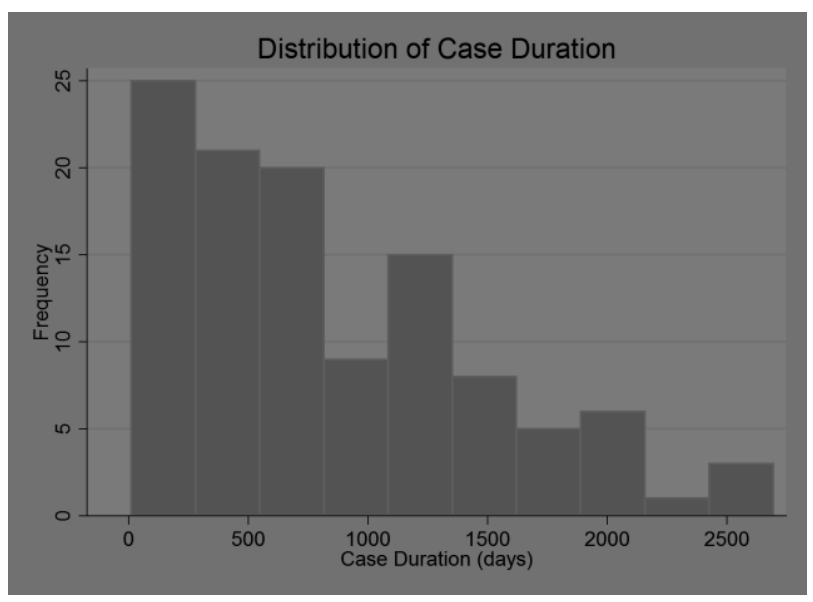

Between August 2001 and June 2010, IMF funded 113 cases, the average length of which was 850 days, or 2.33 years. ${ }^{106}$ Figure 1 presents the case duration distribution, which is right-skewed. A handful of cases continued without resolution for many years, but the bulk of the cases are resolved within the first two years.

During this time period, IMF received an internal rate of return of seventy-five percent before overhead expenses. ${ }^{107}$ Profits for most cases

104. Letter from John Walker, Exec. Director, IMF (Australia) Ltd, to Laurie Glanfield, Secretary, Standing Committee of Attorneys-General, (Aug. 11, 2006) (on file with the University of Pennsylvania Journal of Business Law).

105. David S. Abrams \& Daniel L. Chen, IMF Lawsuit Financial Data (Sept. 8, 2010) (unpublished spreadsheets) (on file with the author) [hereinafter Abrams \& Chen, IMF

Data]. These documents are confidential and cannot be distributed publicly.

106. Id.

107. Id. 
ranged between a loss and gain of less than a million Australian dollars (AUD). As would be expected, losses are limited, and there are some notable cases with profits of several million AUD. ${ }^{108}$

\section{Figure 2. Distribution of Profits Per Case}

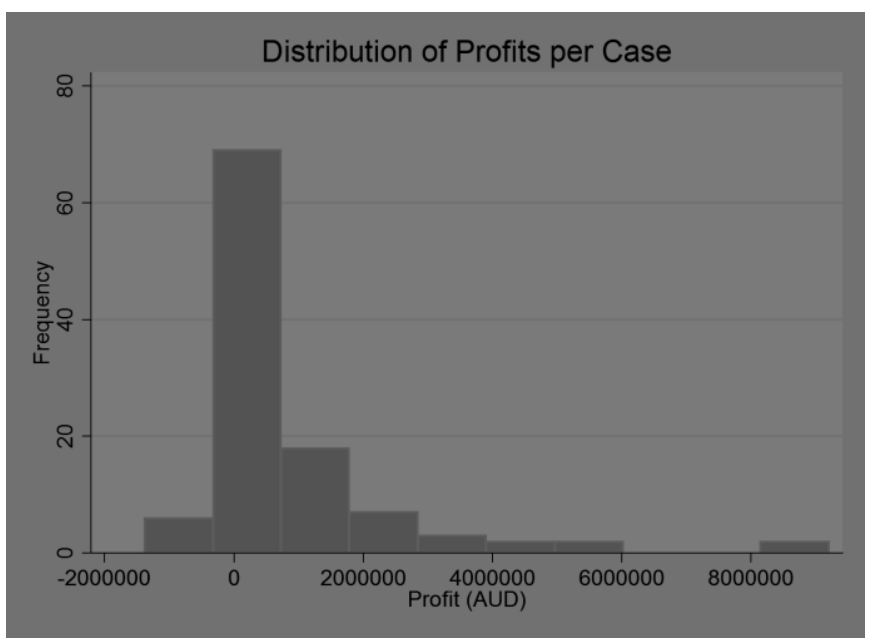

Thirteen of the 113 cases actually went to court and were resolved by judicial opinion. From February 1999 to June 2007, IMF chose to fund 91 of the 763 cases considered. ${ }^{109}$ The data available on cases considered includes the date opened, cause of action, management commentary, IMF investment manager, IMF state manager, estimated return, and the estimated completion date. ${ }^{110}$ From IMF's shareholder publications, we also obtained the jurisdictions of the cases that were funded from 2001 to $2003,{ }^{111}$ the case categories for all cases funded from 2004 to $2007,{ }^{112}$ and the total litigation contracts in progress from 2002 to $2008 .^{113}$

Cases are classified primarily into three categories: commercial (often contract disputes), group (class action), and insolvency. The distribution across case type can be found in Table 1. Insolvency cases are the largest category, but this is largely attributable to the historic origins of litigation

108. Id.

109. Abrams \& Chen, IMF Data, supra note 105.

110. Id.

111. Alden Halse \& Hugh McLernon, IMF (Australia) Ltd, IMF (Australia) Ltd August 2003 Presentation (Aug. 2003) (on file at the University of Pennsylvania Journal of Business Law).

112. IMF (Australia) LtD, 2008 AnNuAl Report (June 30, 2008), available at http://www.imf.com.au/annualreports.asp.

113. Id. at 53. 
funding. ${ }^{114}$ Since bankruptcy was the one domain where purchasing litigation has historically been allowed, many of the earliest cases fall into this category. More recent cases represent a more diverse set of legal fields.

\section{Table 1}

\section{Distribution of Funded Case Types}

\begin{tabular}{|c|c|c|}
\hline & Frequency & Percent \\
\hline Commercial & 21 & 23 \\
\hline Group & 28 & 31 \\
\hline Insolvency & 42 & 46 \\
\hline Total & 91 & 100 \\
\hline
\end{tabular}

Our second data source is the Australian Report of the Government (ROGS). ${ }^{115}$ From this source we obtained data on the supreme and federal courts for each Australian state ${ }^{116}$ separated by civil and criminal matters for the years 1994 to $2009 .{ }^{117}$ The advantage of having criminal as well as civil data is that the criminal cases should not be affected at all by litigation funding. Thus, this data acts as a control group. The data includes lodgments, finalizations, several measures of expenditures and income, case backlog, case duration, clearance rate, court fees, and attendances (appearances) per finalization. ${ }^{118}$ We also make use of population data for each state obtained from the Australian Bureau of Statistics, from which we create per capita lodgments and finalizations. ${ }^{119}$

114. John Walker, IMF (Australia) LTD, Submissions on State Regulation of LiTIGATION FUNDING 4 (2005); WAYE, supra note 1, at 5.

115. Australian Gov't Productivity COMm'N, Report on GOVERnMent SERVices, http://www.pc.gov.au/gsp/reports/rogs (last visited Jan. 30, 2011). Not all variables were available for all years.

116. See Figure 3, infra, for a map of Australia.

117. Report on Government Services, supra note 114.

118. For a definition of these variables, please see the Appendix.

119. Australia Bureau of Statistics, Australian Demographic Statistics, http://www.abs.gov.au/AUSSTATS/abs@.nsf/second+level+view?ReadForm\&prodno=310 1.0\&viewtitle $=$ Australian\%20Demographic\%20Statistics $\sim$ Jun\%202010 Latest $\sim 21 / 12 / 2010$ 
Figure 3. Map of Australian Jurisdictions ${ }^{120}$

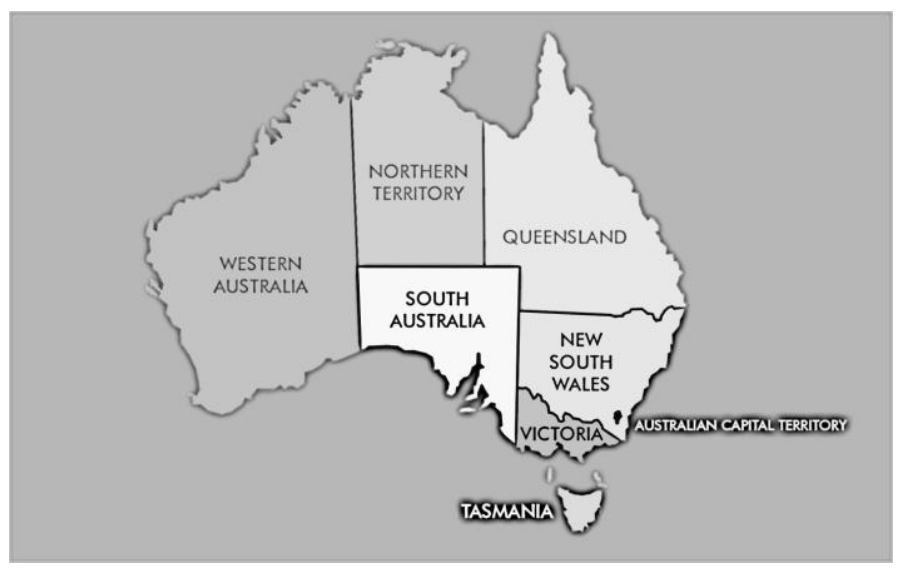

The third data source is LexisNexis Australia, from which we obtained data on all published opinions for cases considered by IMF between February 1999 and June 2007. Within the Lexis database, we searched for each of the 763 cases considered, locating a total of sixteen unfunded cases and seven funded cases. ${ }^{121}$ For each of these cases we collected data regarding the date, attorneys, court, litigants, judge, citations to other cases, subsequent positive and negative citations, and more detailed information about the case. ${ }^{122}$ This data was used to examine the effect of litigation funding on the establishment of precedent.

\section{ANALYSIS}

The ideal experiment to test the theories described above would consist of a law change randomly chosen to take place in certain (treatment) jurisdictions and not in other (control) jurisdictions. One could then compare outcomes of interest such as settlement rates, settlement amounts, time to settlement, court caseload, court expenditures, and the

\&\&tabname $=$ Past $\% 20$ Future $\% 20$ Issues $\&$ prodno $=3101.0 \&$ issue $=$ Jun $\% 202010 \&$ num $=\&$ vie $\mathrm{w}=\&$ (last visited Jan. 30, 2011).

120. Australia States Rs01 - Australia Maps, Mapsof.NET, http://mapsof.net/map/australia-states-rs01\#.UWRWCBIXxcJ (last visited Apr. 9, 2013).

121. The LexisNexis searches were based on the description that IMF recorded for each case considered.

122. David S. Abrams \& Daniel L. Chen, LexisNexis Australia Compilation of Opinions from IMF Considered \& Funded Cases (2010) (unpublished document) (on file with the author) [hereinafter Abrams \& Chen, LexisNexis Australia Data]. 
development of precedent, between the treated and control jurisdictions. Because of the recent changes in the attitudes toward litigation funding in Australia, we have a situation that comes close to the ideal experiment.

However, reality differs from the ideal in several important ways. First, while some Australian states have officially discarded maintenance and champerty doctrines, others have not; those that have not still allow litigation funding. ${ }^{123}$ Second, the timing of the introduction of litigation funding in a state is not always coincident with the law change. Third, data on many of the most interesting outcome variables (particularly on settlements) is impossible to obtain.

With these limitations in mind, we proceed with an analysis that is as close to the ideal experiment as possible. As a proxy for the change in maintenance and champerty laws across jurisdictions, we use the amount of money IMF spent in a particular jurisdiction at a particular time. This becomes the key variable of interest in our regressions and serves as a measure of how open a particular state is to litigation funding. What we would like to do is determine the impact of the funding on various outcomes, while accounting for the fact that states have other differences besides funding levels and that funding can also vary over time for other reasons. In regression form:

\section{EQUATION 1.}

$$
\text { Outcome }_{j t}=\beta^{*}\left(\text { Funding }_{j t}\right)+\delta_{t}+\gamma_{j}+\varepsilon_{j t}
$$

where $t$ indexes year and $j$ indexes jurisdiction. Outcome $e_{j t}$ is one of the variables from the ROGS reports: lodgments, finalizations, several measures of expenditures and income, case backlog, case duration, clearance rate, court fees, and attendances (appearances) per finalization. $\delta_{t}$ and $\gamma_{j}$ and are fixed effects for jurisdiction ${ }^{124}$ and year, which allow for overall differences unrelated to funding levels in outcomes by state and year, respectively. ${ }^{125}$

In order to have a causal interpretation in the above regression, the variation of litigation funding across jurisdictions must be assumed to be

123. WAYE, supra note 1, at 55-78. Mere funding is not maintenance and mere funding for reward is not champerty. Impropriety needs to be proved. Litigation funding firms can fund in the States and Territories that have not abolished maintenance and champerty, and if challenged, these firms merely need to prove that their funding is not improper maintenance. See supra Part 0 (citing examples where courts have found that litigation funding was not improper maintenance).

124. Because we use state fixed effects, a jurisdiction that has no IMF expenditures during our timeframe will drop out in our analysis.

125. We use robust standard errors and do not cluster our standard errors at the state level since our dataset would only have seven clusters -- too few by conventional standards. 
exogenous. It is possible that there are jurisdiction-year characteristics that attract funding and are also related to the outcomes of interest. To address this challenge to a causal interpretation, we make use of what is effectively a placebo: criminal cases. Because litigation funding is only allowed in civil cases, one would not expect any impact on criminal cases. These cases may thus be employed as a control for any unobservable overall changes in a jurisdiction at a particular time. We should then be able to draw a causal inference about the impact of more litigation funding on civil outcomes in a particular jurisdiction at a particular time. Thus, the dependent variable is the difference between the particular outcome measure for civil cases and for criminal cases.

\section{EQUATION 2.}

$$
\left(\text { Outcome }_{j t}^{\text {civil }}-\text { Outcome }_{j t}^{\text {crim }}{ }_{j t}\right)=\beta^{*}\left(\text { Funding }_{j t}\right)+\delta_{t}+\gamma_{j}+\varepsilon_{j t}
$$

Before proceeding to the main results, we first present in Figures 4-7 the variation in IMF funding over time in four Australian states. Although decreasing somewhat in 2008, New South Wales has seen relatively consistent funding levels of several million AUD per year between 2002 and 2007. The spending in Queensland is more volatile: spending was approximately one million AUD in 2002; it dropped off sharply through 2005, and since 2006 has recovered to some extent. Victoria has seen higher levels of funding than Queensland; however, its funding peaked in 2005 and has declined somewhat since then. Finally, Western Australia has seen a fairly steady growth in funding and was the only state examined to have an increase in funding in 2008. One of the important points to note from a comparison of the temporal funding patterns is that there is a substantial amount of variation across the states. This adds confidence to the assumption that funding is not driven simply by overall national time trends. 
Figure 4. IMF Annual Expenditures in New South Wales ${ }^{126}$

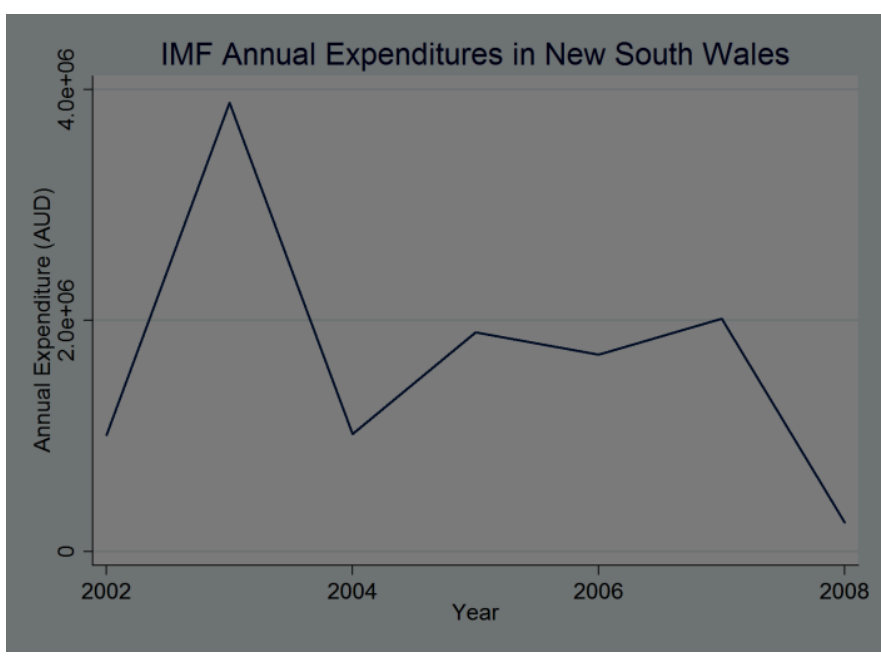

Figure 5. IMF Annual Expenditures in Queensland ${ }^{127}$

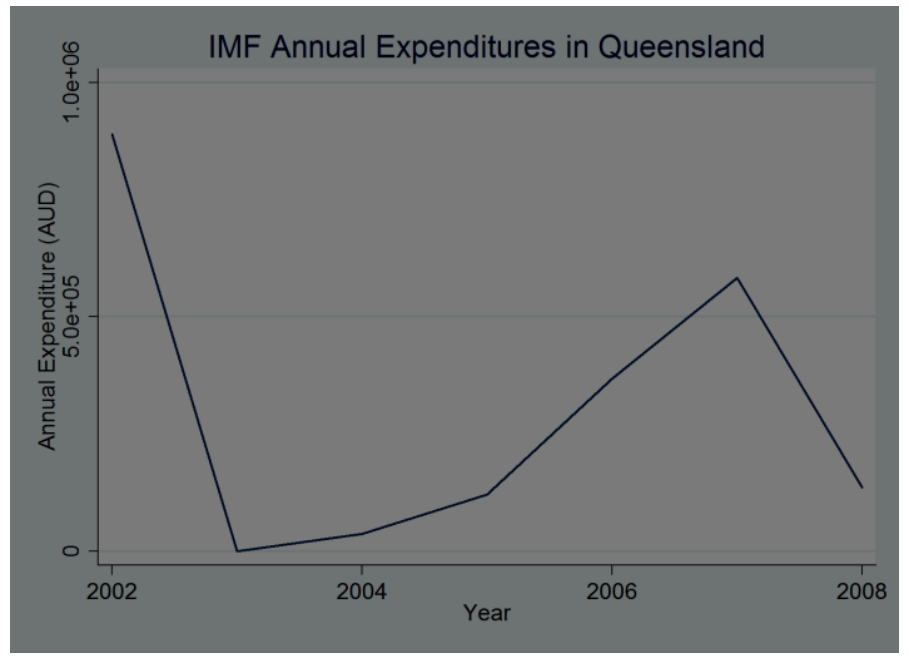

126. Abrams \& Chen, IMF Data, supra note 105.

127. Abrams \& Chen, IMF Data, supra note 105. 
Figure 6. IMF Annual Expenditures in Victoria ${ }^{128}$

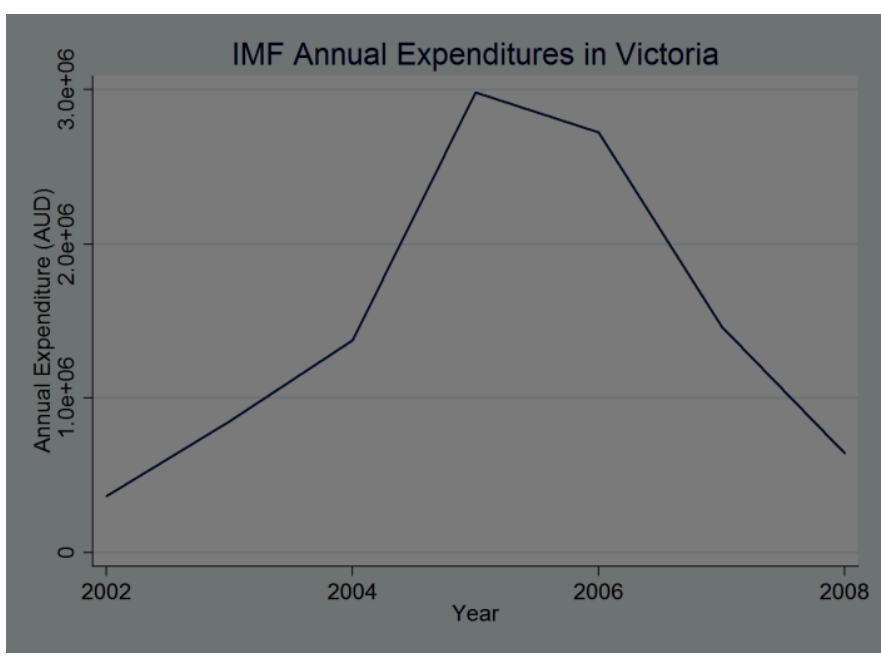

Figure 7. IMF Annual Expenditures in Western Australia ${ }^{129}$

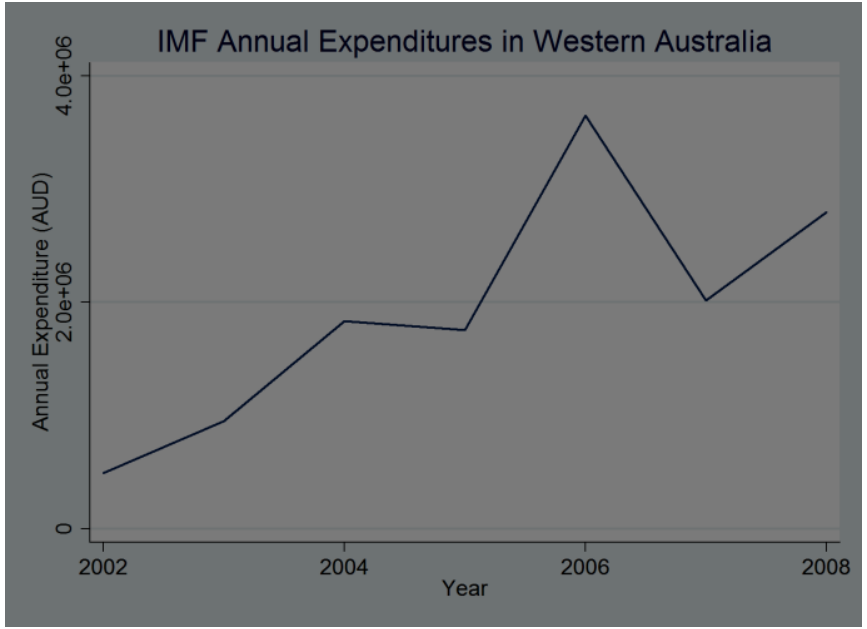

The main results of the regression analysis are presented in Panel A of Table 2, infra page 133. The table presents results from nine separate regressions, each using the specification described in Equation 2, supra page 127, with the dependent variable noted at the top of each column. The coefficient of interest is that on IMF expenditures and robust standard

128. Abrams \& Chen, IMF Data, supra note 105.

129. Abrams \& Chen, IMF Data, supra note 105. 
errors are reported in parentheses.

Several interesting findings are apparent in the table. First, finalizations decrease with increased funding (column 2), although lodgments do not change a statistically significant amount (column 1). The combination of these observations suggests that cases tend to take longer to conclude when a litigation funder enters the legal market. There are several other pieces of evidence that point in the same direction. The backlog of non-appealed civil cases increases substantially relative to the non-appealed criminal backlog as IMF spending increases (column 6). As one might expect, it appears that finalizations decrease and the backlog increases. The clearance rate also declines to a statistically significant degree as third party funding increases (column 7). Finally, even when normalizing finalizations by population size, one sees a significant (at the ten percent level) decline with increased funding (column 8).

Table 2: Impact of Third-Party Funding on Court Processing

\begin{tabular}{|c|c|c|c|c|c|c|c|c|c|}
\hline & $\begin{array}{c}\text { Lodgments } \\
\text { (1) }\end{array}$ & $\begin{array}{c}\text { Finalizations } \\
\text { (2) }\end{array}$ & $\begin{array}{c}\text { Recurrent } \\
\text { Expenditures } \\
\text { (3) }\end{array}$ & $\begin{array}{c}\text { Net } \\
\text { Expenditures } \\
(4)\end{array}$ & $\begin{array}{c}\text { Backlog, } \\
\text { Appeals } \\
\text { (5) }\end{array}$ & $\begin{array}{c}\text { Backlog, } \\
\text { Nonappeals } \\
(6)\end{array}$ & $\begin{array}{l}\text { Clearance } \\
\text { Rate } \\
\text { (7) }\end{array}$ & $\begin{array}{c}\text { Finalizations } \\
\text { Population } \\
(8)\end{array}$ & $\begin{array}{c}\text { Attendances / } \\
\text { Finalization } \\
\text { (9) }\end{array}$ \\
\hline \multicolumn{10}{|l|}{ Panel A } \\
\hline IMF Expenditures $_{t}$ & $\begin{array}{l}-0.240 \\
(0.204)\end{array}$ & $\begin{array}{c}-0.434 \\
(0.210)^{*}\end{array}$ & $\begin{array}{c}846.2 \\
(522.2)\end{array}$ & $\begin{array}{c}1118.2 \\
(391.2)^{* * *}\end{array}$ & $\begin{array}{l}-0.00514 \\
(0.00562)\end{array}$ & $\begin{array}{c}0.00704 \\
(0.00200)^{* * *}\end{array}$ & $\begin{array}{c}-0.0135 \\
(0.00408)^{* * *}\end{array}$ & $\begin{array}{c}-0.00824 \\
(0.00466)^{*}\end{array}$ & $\begin{array}{c}0.000223 \\
(0.000232)\end{array}$ \\
\hline $\mathrm{N}$ & 35 & 35 & 35 & 35 & 30 & 30 & 30 & 35 & 23 \\
\hline $\mathrm{R}^{2}$ & 0.960 & 0.956 & 0.984 & 0.943 & 0.283 & 0.684 & 0.611 & 0.828 & 0.680 \\
\hline \multicolumn{10}{|l|}{ Panel B } \\
\hline IMF Expenditures $\mathrm{t}_{\mathrm{t}-1}$ & $\begin{array}{l}-0.182 \\
(0.198)\end{array}$ & $\begin{array}{l}-0.0853 \\
(0.353)\end{array}$ & $\begin{array}{l}-1502.7 \\
(1044.5)\end{array}$ & $\begin{array}{l}-1377.1 \\
(790.3)^{*}\end{array}$ & $\begin{array}{c}0.00249 \\
(0.00385)\end{array}$ & $\begin{array}{c}0.00252 \\
(0.00261)\end{array}$ & $\begin{array}{c}0.00278 \\
(0.00580)\end{array}$ & $\begin{array}{c}-0.00213 \\
(0.00724)\end{array}$ & $\begin{array}{c}-0.000193 \\
(0.000235)\end{array}$ \\
\hline $\mathrm{N}$ & 30 & 30 & 30 & 30 & 30 & 30 & 30 & 30 & 23 \\
\hline $\mathrm{R}^{2}$ & 0.981 & 0.949 & 0.986 & 0.958 & 0.239 & 0.589 & 0.475 & 0.801 & 0.678 \\
\hline \multicolumn{10}{|l|}{ Panel C } \\
\hline IMF Expenditures $\mathrm{t}_{\mathrm{t}+1}$ & $\begin{array}{l}-0.349 \\
(0.234)\end{array}$ & $\begin{array}{l}-0.270 \\
(0.197)\end{array}$ & $\begin{array}{l}-268.3 \\
(745.1)\end{array}$ & $\begin{array}{l}-693.8 \\
(817.9)\end{array}$ & $\begin{array}{c}0.00129 \\
(0.00495)\end{array}$ & $\begin{array}{l}0.000832 \\
(0.00527)\end{array}$ & $\begin{array}{l}-0.00940 \\
(0.00563)\end{array}$ & $\begin{array}{l}-0.00266 \\
(0.00457)\end{array}$ & $\begin{array}{c}0.000581 \\
(0.000275)^{*}\end{array}$ \\
\hline $\mathrm{N}$ & 30 & 30 & 30 & 30 & 25 & 25 & 25 & 30 & 19 \\
\hline $\mathrm{R}^{2}$ & 0.960 & 0.956 & 0.981 & 0.935 & 0.284 & 0.591 & 0.578 & 0.833 & 0.686 \\
\hline
\end{tabular}


Together, these regression results tell a consistent story: an increase in activity of litigation funders leads to more sclerotic courthouses. One might expect this increased litigation to be reflected in greater spending by the courts, and indeed columns 3 and 4 bear this out. While the coefficient on recurrent expenditures (column 3) is insignificant, the measure of expenditures that is more responsive to caseload fluctuations is net expenditures, which does have a statistically significant relationship with IMF expenditures. Overall, we see a pattern of increased funding corresponding to slower case processing, larger backlogs, and increased spending by the courts.

In the next section we discuss the robustness and significance of these findings and explore some possible channels for these results. For example, Panel B shows that IMF expenditures are not correlated with court processing outcomes in the year following the IMF expenditures.

First, we present the findings from the other main analysis undertaken, a comparison between funded and unfunded published cases (Table 3). From the universe of cases that IMF considered funding, we collect all with published opinions found in LexisNexis Australia. We compare the number of citations from and to other cases for the seven funded and sixteen unfunded published cases. There is a substantial difference in both measures of case significance. Funded cases cite almost forty other cases on average, while cases IMF chose not to fund cite fewer than twenty.

Even more indicative of case significance is the number of times funded cases have been cited. Here we find eleven citations on average for funded cases in comparison to fewer than five citations for the unfunded cases. The magnitude of the differences is extremely large. To the extent that citations are a good proxy for precedential importance, it appears that when litigation funders enter a market, they create more precedent earlier on. One potential concern may be that the funded cases are older, on average, than unfunded cases and have therefore had more time to gather cites. The funded cases are slightly older, less than 6 months on average, which is not enough to explain a disparity of this magnitude. We explore the robustness of the findings presented thus far in the next section. 


\begin{tabular}{|l|l|l|l|}
\hline \multicolumn{4}{|c|}{ Table 3. Citation Rates by Funded Status } \\
\hline & Funded & Not Funded & Ratio \\
\hline $\begin{array}{l}\text { Citations to } \\
\text { Other Cases }\end{array}$ & 38.7 & 19.0 & 2.0 \\
\hline $\begin{array}{l}\text { Citations to the } \\
\text { Case }\end{array}$ & 11.0 & $(22.7)$ & \\
\hline Observations & 16 & 4.6 & 2.4 \\
\hline
\end{tabular}

\section{ROBUSTNESS AND INTERPRETATION}

Since our identification strategy relies on changes in IMF expenditures across states and across time, the biggest concern to a causal interpretation is that IMF expenditures may themselves be driven by other factors that correlate with court processing. Moreover, the results presented so far do not rule out the possibility of reverse causality. Demand for third-party litigation funding may be greatest when the courts are the most backlogged. We address this concern in several ways. First, we look one year before the IMF expenditures to see if court processing is driving demand for third party litigation funding. Second, we use financial data on cases that IMF considered, both funded and non-funded, as a proxy for demand for thirdparty litigation funding.

One possible explanation for the results discussed thus far is that more congested courts attract more third-party funding. We test this by running the same regressions as presented in panel A of Table 2, but using IMF expenditure data from the year after the court processing data. We find (Panel $\mathrm{C}$ of Table 2) that no court processing measure is related to IMF expenditures in the year before the IMF expenditures occurred, except for attendances per finalization. This provides some support for IMF expenditures being unrelated to court processing.

Even though we use criminal cases as a control group to address

\footnotetext{
130 The figures in parentheses represent standard deviations. Abrams \& Chen, LexisNexis Australia Data, supra note 122.
} 
possible omitted variables, there are some omitted variables that may be specific to civil cases and litigation funding that could be correlated with court processing. For example, if IMF funding is representative of overall litigation funding and the other fifty percent of unmeasured litigation funding happens precisely where IMF funding occurs, then our estimates would be overestimated by a factor of two. On the other hand, if IMF is active precisely where the other fifty percent of litigation funders are not active, then our estimates would be understated, although in the extreme case, we would not be able to estimate any effects at all. This is likely not the case given the fact that some states still have champerty and maintenance facing criminal penalties on the books, even though it is not strictly enforced.

Alternative litigation funding is not the only source of omitted variable bias, however. Arbitration and contingency fee arrangements are also unmeasured. The same logic applies as in the case of alternative litigation funding. Here, it may very well be the case that these alternative funding arrangements compete, in which case our estimates are overestimates. Alternatively, if arbitration and contingency fees are used by the clients who were rejected by IMF or other litigation funders, then our tests using the measure for demand for litigation funding would alleviate this omitted variable concern.

Finally, we return to the issue of the development of law and establishment of precedent. Different courts may have different citation patterns and later cases may receive fewer citations than earlier ones. In Table 4, we improve upon the citation statistics reported in Table 3 by allowing for those possibilities. We find that funded cases still receive more total citations and that this is statistically significant at the ten percent level. If we included cases that did not go to court (or otherwise were not able to be found in Lexis Australia) as receiving no citations, then the estimated effects of funding are vastly more significant, as about eight percent of funded cases had an opinion but roughly two percent of nonfunded cases had an opinion. 
Table 4: Impact of Funding on Development of Law -- Robustness Check

\begin{tabular}{lccc}
\hline \hline & Log Total Cites & Log Positive & Log Cases This \\
& & Cites & Cited \\
& $(1)$ & $(2)$ & $(3)$ \\
\hline Funded & 0.869 & 0.346 & 0.578 \\
& $(0.445)^{*}$ & $(0.284)$ & $(0.493)$ \\
$\mathrm{N}$ & 23 & 23 & 23 \\
$\mathrm{R}^{2}$ & 0.243 & 0.202 & 0.139 \\
\hline
\end{tabular}

Regressions run using case-level observations obtained from the Australia Lexis-Nexis reports for cases that IMF considered and had a published opinion. All logs are of 1 plus the original value to avoid dropping zeros. These regressions include court fixed effects and a linear time trend. Robust standard errors in parenthesis. ${ }^{* * *} \mathrm{p}<0.01,{ }^{* *} \mathrm{p}<0.05,{ }^{*} \mathrm{p}<0.10$

We additionally make use of data on the reversal rate of these cases. The funded cases are reversed twenty-five percent of the time. At first glance this suggests that litigation funding still has taint, as the courts do not appear to consider the law to have as precedential value for funded cases. In the respective jurisdictions and years, only five percent of cases are reversed. However, non-funded but considered cases are reversed thirty-one percent of the time. This suggests that the high reversal rate may actually be due to selection, and conditional on seeking IMF funding, funding actually decreases reversal rate. ${ }^{131}$

\section{CONCLUSION}

Ambitious statements have been made about the potential impact of allowing a market in litigation claims. Predictions include effects on settlement rates, settlement amounts, time before a settlement, litigation quantity, and development of precedent. In this paper we have sought to conduct the first empirical test of some of these claims using several newly-obtained datasets from Australia.

We find that litigation funders appear to have an impact on the functioning of courts. States that have a greater litigation funding presence experience a greater backlog in courts, fewer finalizations, and a lower clearance rate. This is also reflected in court expenditures, which increase with greater litigation funding.

While congesting the courts may be a cost of third-party funding, the

131. This analysis does not address the conventional view of taint, where a jury finds out that the damages being awarded to a party are actually going to a litigation funder. None of the cases where we found opinions in Lexis Australia had juries. 
overall welfare effects could still be positive. If the value of the adjudication of cases is greater than the expense of adjudicating them, then third party funding should be encouraged. Further, court congestion may be a transitory effect of the entry of litigation funders, and not one that persists. The expectation would be that once defendants recognize the increased likelihood of litigation and the greater resources held by plaintiffs, they would be more likely to settle in equilibrium. While transitioning to that new equilibrium, there is another potential benefit from litigation funding: earlier resolution of the law.

Litigation funding does appear to have precedential value. By two different measures, cases funded by IMF have greater importance than those they did not fund, but which proceeded to trial in any case. Funded cases both cite and receive over twice as many references as unfunded cases. If citations are a good proxy for legal precedent, then third-party funding appears to promote its more rapid development. While a full welfare analysis is well beyond the scope of this paper, the closest realworld attempt at a market in litigation claims has had a meaningful impact on the judicial system in Australia. 


\section{APPENDIX: DATA DEFINITIONS}

BACKLOG INDICATOR - A measure of case processing timeliness. It is the number of pending cases older than the applicable reporting standards, divided by the total pending caseload (multiplied by one hundred to convert to a percentage).

LODGMENTS - The initiation or commencement of a matter before the court. The date of commencement is counted as the date of registration of a court matter.

FINALIZATION - The completion of a matter so it ceases to be an item of work to be dealt with by the court. Finalizations are derived from timeliness data that may not reflect the total matters disposed by the courts in the reporting period.

ClEARANCE RATE - A measure of whether a court is keeping up with its workload. It is the number of finalizations in the reporting period, divided by the number of lodgments in the same period (multiplied by one hundred to convert to a percentage).

ATTENDANCE INDICATOR - The average number of attendances for each finalization in the reporting period. An attendance is defined as the number of times that parties or their representatives are required to be present in court (including any appointment which is adjourned or rescheduled) for all finalized matters during the year. The actual attendance is one that is heard by a judicial officer or mediator/arbitrator.

NET EXPENDITURE - Net expenditure refers to expenditure minus income (where income is derived from court fees and other revenue but excludes fines).

RECURRENT EXPENDITURE - Recurrent expenditure provides an estimate of annual service costs. Recurrent expenditure on courts administration includes judiciary and in-court expenditure, court and probate registries, sheriff and bailiff's offices, court accommodation and other overheads. The components of the expenditure include salary and non-salary expenditure, court administration agency and umbrella department expenditure, and contract expenditure. Total recurrent expenditure by Australian, State and Territory court authorities (excluding the High Court and specialist courts) was \$1.2 billion in 2004-05. 
POPULATION - A lodgment that is yet to be finalized but is part of the case management of court administrators. 